\title{
»The walls ought to be demolished from the inside«: KRUM and the failure of the prison struggle in Sweden in the 1960s and 70s ${ }^{1}$
}

Av Roddy Nilsson, professor, Institutionen for historiske studier, Göteborgs universitet

\begin{abstract}
Swedish
Artikeln behandlar fångkampen i de svenska fängelserna vid 1960-talets slut och 1970-talets början. Framför allt diskuteras den roll Riksförbundet för Kriminalvårdens humanisering (KRUM) spelade. Delvis $i$ motsättning till den tidigare forskningens uppfattningen att fängarnas relativa nederlag kan förklaras av en kombination av en svag förhandlingsposition, otillräcklig förhandlingskompetens, motpartens överlägsna resurser och taktiska skicklighet och vikande stöd från media, argumenterar artikeln för att nederlaget också måste förstås $i$ relation till brister $i$ fångarnas strategi och till otillräckligheten $i$ den maktmodell, med betoning framför allt på abstrakta rättigheter, som fanns inom KRUM. På den sistnämnda punkten kolliderade KRUM:s liberalt dominerade modell tydligt med den syn på fången som vuxit fram inom den svenska kriminalvården under decennierna efter andra världskriget.
\end{abstract}

\begin{abstract}
English
The article deals with a struggle for inmates' rights in Swedish prisons at the end of the 1960s and the beginning of the 1970s. The focus is on the role played by the Swedish National Association for the Humanization of Prisons (KRUM). Previous research has argued that the inmates ultimately lost their struggle due to a combination of their weaker bargaining position, their lack of negotiation skills, their counterpart's superior tactical skill and resources, and declining support for their cause in the media. The current article contends that the defeat must also be understood in relation to deficiencies in the prisoners' strategy and to the inadequacy of the power model, with its emphasis on abstract rights, which existed within KRUM. On the latter point, KRUM's liberal-dominated model clearly
\end{abstract}

1. The quote in the title is taken from an editorial in Sweden's biggest newspaper, Dagens Nyheter 710118, Sw. "Murarna bör rivas inifrån". 
clashed with the view of the prisoner that has emerged within the Swedish Correctional Service since World War II.

\section{Introduction}

In October 1970 between two and three thousand Swedish prisoners - about half of the country's prison population - were on strike. ${ }^{2}$ This mass action was the beginning of the most intense and turbulent phase of prison struggle in Sweden. The prisoners had strong support from the National Association for the Humanization of Prisons (KRUM) as well as from an overwhelming majority of Sweden's leading newspapers. For a brief moment in Swedish history, it looked as though the prison system really was beginning to crumble, and that the prisons were about to be transformed. As we all know, this is not how things turned out. Nevertheless, in a time when "prison reform" seems like an out-dated concept, there is good reason to look back on a period when it had a central position in prison discourse.

The work carried out by KRUM and its sister organisations, KROM in Norway and KRIM in Denmark, was a challenge against what David Garland famously coined "penal welfarism", i.e. foregrounding individualized treatment, indeterminate sentences, a considerable amount of institutional discretion and a row of non-custodial sanctions such as parole, probation and social service work (Garland 1985). In this article, I will discuss some aspects of KRUM's aims and position in the prison struggle, especially their critique of the existing prison system and the role of prisoner's rights. The use of rights as a central concept in the prison reform effort is especially interesting given that rights have generally held a relatively weak position in twentieth-century Swedish politics, not least due to the influence of the Uppsala school of legal realism (Källström 1984; Molander 2002).

\section{KRUM in the context of the 1960s and ' $70 \mathrm{~s}$}

$K R U M$ was an important - perhaps the most important - actor in the establishment of a new attitude towards criminal policy in Sweden during the late 1960s

2. The exact number is impossible to calculate. Unsurprisingly, KRUM and the supportive press gave quite different numbers compared to the prison authorities. It is, however, clear that the strike had much more support in the large central prisons then in the smaller local facilities. 
and early 1970s. ${ }^{3}$ During a ten-year period from 1966 to 1975 , KRUM engaged in a wide variety of activities in connection with the prison system, ranging from public meetings, publicity work and demonstrations, to direct personal support work for the benefit of inmates and ex-inmates.

At the same time, $K R U M$ was part of the increasingly radicalized political milieu of the late 1960s. During this period, the political landscape changed in fundamental ways as new social and political movements and organizations developed outside the parliamentary system (Salomon 1996; Östberg 2002; Bjereld \& Demker 2005). Together with a number of other associations, $K R U M$ formed the "R-alliance", also called the "clients' movements" or the "symptom associations" during the latter half of the $1960 \mathrm{~s} .{ }^{4}$ Their joint publication, Pockettidningen $R$, was influential in the discussions concerning social problems and criminal policy. However, the most well-known of the movements that emerged during this period was the Swedish $F N L$ groups, abbreviated $D F F G$, which became the centre for protests against the USA and the Vietnam War, and has gained an almost iconic position in Swedish historiography dealing with this period (Lundberg 1993; Salomon 1996; Östberg 2002).

$K R U M$ was founded by the "parliament of thieves" in the late summer of 1966. The organization was based on the idea of cooperation between prison activists, ex-inmates and inmates. KRUM quickly became a gathering place for people who were committed to changing the situation in Swedish prisons. For the following discussion it is, however, important to note that $K R U M$, especially during the early years, was linked to the liberal party, primarily through Sveriges Liberala Studentförbund (SLS). ${ }^{5}$ In the middle of the 1960s SLS strongly engaged

3. The following description of KRUM and its activities during the prison struggle build, unless otherwise stated, on Nilsson 2013 and 2017.

4. Besides KRUM, Riksförbundet för Hjälp åt Narkotika- och Läkemedelsberoende (RFHL), Riksförbundet för Social och Mental hälsa (RSMH) and Alkoholproblematikers Riksorganisation (ALRO).

5. Sveriges Liberala Studentförbund (SLS) should not be confused with Folkpartiets ungdomsförbund (FPU), the "official" youth branch of the Peoples Party, now the Liberals. During the 1960s clear tensions developed between $S L S$ and FPU, especially after SLS decided to open up for membership also to non-students in 1965. SLS argued for a more free position from the mother party and emphasized that their role primarily was to propagate liberal ideas. During the latter half of the 1960s and beginning of the 1970s SLS became heavily influenced by ideas associated with the "New Left" including a more radical stance regarding prison policy. In 1969 SLS changed its name to Liberala Förbundet (LF), and in 
in areas such as sexual policy, drug policy and prison policy arguing for less repression and more tolerance and freedom. However, the interest in criminal policy and the prisoners' situation developed rather suddenly (Lennerhed 1989:6773).

In the following years $K R U M$ occasionally received considerable parliamentary support from the liberal party as well as from the other two bourgeois parties. As for the ruling social democrats, they usually took a more critical, or at least hesitant, position regarding KRUM (Nilsson 2013:172-173). Hence, KRUM's commitment to the welfare of prisoner's was closely related to other issues taken up by social liberals in the early 1960s: gender roles, sexual liberation, apartheid and drug addiction (Östberg 2008:240-241).

Through the formation of KRUM and the parallel radicalization of the social climate in the late $1960 \mathrm{~s}$, the prison question took on an explicitly political character. KRUM's intervention in the prison question in general, and more specifically in the prison struggle in the years around 1970, was a predominantly liberal attack on the criminal policy in which the prisons and similar institutions were seen as instruments for the training and discipline of working-class men and youths who failed to adapt to the norms of the welfare state. Therefore, on a more general level, KRUM fits into the pattern of criticism directed at the (social democratic) welfare state's deficiencies that became a distinctive feature of many of the movements founded in this period (Östberg 2002:67-80). This critique was inspired by debates about "unfinished welfare" and the burdens of "social heritage", as well as public investigations exposing lingering low-income levels and poor housing conditions among segments of the working class (Inghe \& Inghe 1967; Jonsson 1969; Björkman 2001).

Right from the start, KRUM formulated a strong critique of the Swedish prison administration, especially the Governor General, Torsten Eriksson, while simultaneously advancing reform proposals. These proposals would later be included in a more clearly defined program for improving the conditions in prisons. $K R U M$ initially maintained the existing penal-welfare mentality, arguing for more humanity and "real treatment and care" in prisons and prison-like institutions. The campaign work of KRUM and the prisoners was strongly supported by the liberal press. In particular, Dagens Nyheter, Sweden's biggest daily paper,

1972 to Frihetlig Vänster (FV) and then to Frihetliga Socialisters Förbund. See Lennerhed 1989, 78-86, 95-97. 
stood firmly on KRUM's side. However, support also came from non-bourgeois newspapers (Nilsson 2013:170-190).

During its first years, KRUM's membership grew rapidly, and it quickly became a gathering place for people engaged in reforming the Swedish correctional system, including jurists, journalists, writers, psychiatrists and other doctors, as well as inmates and ex-inmates. In 1968 the number of members reached its peak at around 7000 (Ward 1979:125-130). ${ }^{6}$

Initially, KRUM pleaded for improved treatment within the prisons, but this was soon overshadowed by a focus on the question of prisoners' rights, more specifically the right of prisoners to form their own prisoners' councils and take part in prison administration. During 1968 and 1969, the tensions between KRUM and the prisoners on one side and the prison authorities on the other rose steadily. With the strong support of KRUM, the prisoners formed councils in some of the bigger prisons. When the prison authorities refused to recognize these prisoner representatives, and used force to quell their activities, strikes broke out. By this time the right to form prisoners' councils that could function as bargaining parties vis-à-vis the prison authorities had developed into the central question in the prison struggle.

\section{The height of the prison struggle}

During the spring of 1970, unrest in the prisons intensified, and when more strikes broke out the prison struggle entered its most acute phase. In the autumn of the same year, the situation escalated further as the prisoners in addition to their previous demands, now appealed for direct negotiations on equal terms with the board of the Prison Administration. The struggle was now clearly about nothing less than the democratization of the prisons, an effort in which the right to form prisoners' councils, to assemble and to communicate freely were key components. When the prison authorities promised to make improvements, and agreed to meet the prisoners for further "talks" or "discussions", the action was called off. ${ }^{7}$ In this situation the inmates saw themselves as the winners. One paper described what had happened as a "crushing success" while the journalist and

6. However, a major reason for the quick expansion was that the majority of the members recruited where non-paying prisoners. After 1968, when prisoners had to pay a (reduced) membership fee, the total number of members began to decline.

7. It is important to note that, for procedural reasons, the Prison Administration refused to recognise the meeting as "negotiations". 
KRUM member, Jörgen Eriksson, expressed his enthusiasm over "the biggest step ever towards a humanization of the prisons". ${ }^{8}$ Dagens Nyheter wrote enthusiastically about the "lovely feeling of tearing down prison walls". 9

The now almost legendary meeting between the prisoners and the prison authorities took place at Österåker Prison at the end of 1970. The prisoners presented a long list of demands beginning with the right to organise prisoners' councils and a request that the newly formed Prisoners' Central Organisation (FFCO) be formally recognized. Moreover, a number of improvements and relaxations in the prison regime, including the abolition of compulsory work were called for. The discussions were accompanied by strikes and unrest at several prisons around the country. Although KRUM was not allowed to participate in the discussions directly, representatives belonging to the organisation contributed with advice and juridical expertise. When the prison authorities refused to make any binding promises, pointing to the fact that several of the prisoners' demands required legislative changes, the discussions broke down. However, they were resumed in a small joint working group that prepared for a new meeting in early 1971. This time the Prison Administration promised some improvements including recognition of the prisoners' councils. The prisoners and their supporters began to feel optimistic once again. In the following months some minor improvements were carried out in the prisons. However, it wasn't long before the prisoners began to complain that no concrete changes were being made, which resulted in a new wave of strikes and protests in the summer of 1971. Once again, the prisoners demanded negotiations.

In late 1971 new discussions commenced at Kumla Prison, this time as an initiative of the prison authorities. The prisoners repeated many of the extensive rights issues they had presented previously in addition to a number of new demands, such as the right to wear civilian clothes, and the abolition of body frisks, visitations and lock-ups in cells at night. Further, the list now included the abolition of surveillance during conditional release. This time the meeting was very brief. When the prison authorities once again stated that they could not make any binding promises, the prisoners' representatives walked out and about 1500 inmates went on strike. But this time the strikes had no effect, and the discussions were not re-opened. The prisoners were now met by a much more restrictive attitude from the Prison Administration who acted swiftly, locking down the prisons

8. Expressen 701028, Wilhelm Bexell, "Segerljubel i fängelserna idag".

9. Dagens Nyheter 701029, Rune Johansson, "Vilken härlig känsla att riva fängelsemurar". 
affected by the strike. Media interest was also more limited and after a short time the prisoners' protests ran out of steam. The tensions inside the prisons lingered for several years, and further protests and strikes took place at the end of the summer of 1972 and during the spring of 1973. The last serious attack on the prison system, a partly violent demonstration in Sweden's biggest prison Kumla, took place in 1973.

But the heyday of KRUM and the prison struggle was clearly over. Even at the time of the major prison strikes and the discussions between the inmates and the Prison Administration, KRUM's membership had already began to decline. Thus, in the early 1970s KRUM was showing clear signs of an organisation in crisis (Tham 1972:2-3). The rather disappointing results of the prison struggle fuelled tensions and disagreements, both within KRUM and between KRUM and the inmates, about which strategies to follow in the future. The psychological effects of the disappointments may also have contributed to the decline of KRUM (cf Mathiesen 2017:166). At this time, many of the most high-profile members and leaders during the 1960s and beginning of the 1970s left the association. The new leaders lacked the political connections and media contacts of their forerunners, and, at the same time media interest had begun to cool considerably. In 1975 the number of members had fallen to around 400 (Ward 1979). Talk of dissolving $K R U M$ began in the mid-1970s, but the organization lived on for another decade, although their activity during the final years was irregular (Tham 2004:85-89).

\section{The failure of the prison struggle?}

At the time, the authoritative interpretation of the prison struggle within KRUM was that the prisoners had been defeated and the prison authorities had managed to take control of the process and neutralize the challenges directed at the system (Mathiesen 1974). Thomas Mathiesen, the leading theoretician of the Scandinavian clients' movement, who participated as a close observer and occasional advisor, later presented a detailed study of the events. In this study, he concluded that the main reason prisoners emerged as the losing party, despite strong support from KRUM and the liberal press, was mainly because they were not "positive" contributors to the system. More specifically, according to Mathiesen, they had nothing to withdraw that could seriously affect the system (Mathiesen 1974:127$129 ; 172-173){ }^{10}$

10. For a more developed version of Mathiesen's theoretical model, see Mathiesen 1965. The counter-strategy suggested by Mathiesen was that by refusing to play a game completely 
Faithful to his affiliates, Mathiesen avoided a critique of $K R U M$ and prisoners' actions, something he saved for the Prison Administration. However, the prisoners' decision to advance more and more far-reaching claims, and thereby raising the stakes of the struggle, must be seen as a tactical mistake borne out of a combination of an overestimation of the strength of their own position - not least due to massive media support - and perhaps also impatience and frustration with the sense over that "nothing was happening". The adoption of a more ambitious agenda was also a dangerous tactic because by formulating increasingly radical demands, the inmate negotiators risked their credibility among the prison collective if the discussions should fail; and, ultimately, this is what happened.

What started as a criticism of the absence of humane treatment in prisons developed gradually into a question of prisoners' right's as a step towards prison abolitionism. Thus, the attack on the prison system was directed against the model for individual treatment with roots in somatic medicine, which KRUM and other prison critics saw as a way to control the prisoners and prevent them from collective resistance (e.g. Mathiesen 1972:45-50). In a sense, this critique was directed at a straw man as this kind of treatment never materialized (cf. PeterssonHjelm 2002). Instead, the model that dominated the prison system on the practical level emphasised work-training in industrial prisons or prison colonies. Acording to the social democratic rationality that predominated the prison regimes, the prisoner-subject was someone who should be transformed into a conscientious worker and loyal citizen. Thus, the belief was that the large mass of prisoners was not in need of individual medical or psychiatric treatment, but of being (re)trained to live normal and industrious lives. Moreover, prison work in the decades following the Second World War was not only - as in the classical liberal political economy - aimed at inculcating a general work discipline, but also at training the prisoners in a particular kind of work: industrial work in large productive units organized in the form of piecework (Nilsson 2017).

Consequently, the majority of the prisoners where seen as members of the working class gone astray. For the rest, those belonging to the group of habitual offenders or the Lumpenproletariat, special treatment and/or security arrangements were provided. In practice, however, the conditions for this group were not particularly different, apart from the longer sentences they served. The chances of

controlled by the Prison Administration, the prisoners could step away from the system and develop strategies for forming alliances both "upwards" and "sideways". See Mathiesen 1972, 167-170 and 1974, 173-182. See also, Mathiesen 2015. 
rehabilitation where connected to the prisoners' willingness and ability to embrace their role as workers. However, the prisoners could never be recognized as "real" workers, something that was shown when the short-lived "prisoners union" Swedish Institutional Workers Association (SAAF) applied for membership in The Swedish Trade Union Confederation ( $L O)$ and was turned down. Thus, an ex-prisoner could only be truly reintegrated and re-admitted into society by showing that he was ready to "pull his bits" to the societal whole.

This view of the prisoner as a working subject, a member of the workers collective, must be seen in relation to the general economic and social context of the post Second World War decades. This period was the "golden age" for Swedish industry, mainly due to strong foreign demand for industrial products, something that resulted in unprecedented economic growth but also in a labour shortage (Schön 2010:321-326). Hence, labour policy was driven by the "full employment strategy", which meant that all hands in society - including those of the prisoners - were needed.

However, KRUM's intervention meant a collision between this social democratic model of the prisoner-subject and the image of the subject as a rights' bearing individual that predominated within the association, at least until the beginning of the 1970s. The foremost exponent of the social democratic model was the above-mentioned Torsten Eriksson with whom KRUM had a series of hard clashes before he left office in 1970. Eriksson was closely connected to Swedish social democracy where the support for KRUM and the ideas they propagated was weak. This is not surprising since, right from the start, $K R U M$ gained parliamentary support from the liberal Peoples Party and occasionally also from the other bourgeois parties, in a joint attack on the Minister of Justice, Herman Kling, and social democratic criminal policy in general. ${ }^{11}$

Hence, in retrospect, it is easy to see that many of the prisoners' demands were rather unrealistic, at least in the short term, something that became even more evident when KRUM began to propagate abolitionism. Placing too much emphasis on prison abolition redirected the focus of the movement away from realisable, concrete reforms and towards the realm of uninteresting, and, for those

11. Only after Lennart Geijer and Bo Martinsson had succeeded Herman Kling and Torsten Eriksson on the posts of Minister of Justice and Governor General for the Prison Administration respectively, relations became less strained. However, despite Geijer's reputation for being "prisoner-friendly" he maintained a low profile during the prison struggle. Regarding Geijer and the prison struggle, see Bjereld, 164-171. 
in power, harmless idealism. In addition, if abolitionism is seen as a result of the transformation of class society - a conclusion that could be deducted from KRUM's program - the utopian character of the prison struggle becomes even clearer. The tension surrounding this question showed itself in disagreements within $K R U M$ between those who wanted to concentrate more specifically on penal and correctional reform and those who wanted to pursue a more socialistoriented policy. Also, it seems that, in the end, the increasing and "inflationary" use of the strike weapon was counterproductive.

Media outlets played a central role with their intensive coverage of events, sometimes functioning as a megaphone for KRUM. As it turned out, this almost symbiotic relationship between the prisoners and the media was both a strength and a weakness. As long as KRUM and the prisoners could expect almost unanimous support from the dominant media players, it was hard for the prison authorities to resist the pressure for reforms. When support for the prisoners' began to wane, their position became more problematic.

At the same time, it is too easy to say that KRUM and, more importantly, the prisoners should have had a clearer and more realistic understanding of how difficult it would be to change the prison system, and how institutional needs often defeat rights claims (cf. Easton 2011:29-31). We have to bear in mind that the prison struggle took place in a political and social climate in which demonstrations and direct action were common, and demands for rapid and radical changes could be expected. For those fiercely dedicated to the struggle, the media's overwhelming support for the prisoners may have created a social-psychological climate in which "everything seemed possible". Furthermore, the progressive political climate and the belief that public support was stronger than it really was, may have seduced KRUM and, even more significantly, the inmates, with the thought that this really was the moment in history when the prisons could be transformed.

But this relative failure when it came to prison reform must also be seen in relation to the liberal political thinking predominant within KRUM and occasionally amongst the prisoners' representatives. I shall devote the remainder of this article to this question, pointing out some of the problems with such an understanding of the subject and prisoner rights. First of all, it is important to note that rights in this context should be understood as political and liberal rights, i.e. essentially "negative" rights built upon a model of the subject as rational, industrious and selfinterested, and of rights as something that open up spaces for freedom at the same time as they protect the subject from state encroachment. Understood in theoretical terms, the version of rights inherent in KRUM's program assumes a sovereign subject who, in receiving certain liberal rights, would obtain greater autonomy 
and thus greater ability to control their own life. Furthermore, the liberal subject is presupposed to be ontologically prior to and separate from the relations of power in which the same subject find themselves.

However, the abstract model of the subject associated with liberal theory undoubtedly constructed with the classical bourgeois citizen in mind - is not particularly well suited to those spending time in prison as presupposed theories of what the subject ought to be restricts human possibilities and marginalizes those who fall outside this conception. Rights are not given and decontextualized, but are dependent upon societal patterns of behaviour and normative acceptance something that is especially pertinent when considering prisoners and other deviant groups (Golder 2015:105). Furthermore, the "freedoms" at stake in the prison struggle are always power-dependent, and thus find their expression in the disciplinary process. Hence, the focus on formal liberal rights within the prison struggle created a veil that drew the attention away from the power relations produced by these same rights, i.e. between the prisoners and the prison authorities, but also between KRUM and the prisoners and between different groups of prisoners.

As described by Michel Foucault, the liberal conception of power is primarily associated with the state and its relations to its subjects. This is an essentially negative form of power seen in punishments, prohibitions and other sanctions (see e.g. Golder \& Fitzpatrick 2009:12-25). Foucault famously juxtaposed this negative "sovereign" power with disciplinary power, i.e. a "positive", productive power making use of techniques like spatial distribution, hierarchical observation, surveillance, examination and normalizing judgment, particularly important in institutional settings like prisons, schools, and hospitals (Foucault 1991). But these different types of power are also complementary and reinforce each other, making the prison an even more complex and resistant institution (Pickett 2006:78-96; Golder \& Fitzpatrick 2009:13-25; Golder 2015:45-46). Hence, due to the role played by other forms of power in modern society, most importantly discipline, legal provisions of power can never be the sole focus in political and social struggles.

Furthermore, the rights discourse can be used in different ways. By agreeing that rights are necessary, albeit interpreted in a different way, the Prison Administration could signal their progressiveness and willingness to compromise. During the intense phase of unrest in the Swedish prisons the new Governor General, Bo Martinsson, wrote: 
$[\ldots]$ there is nothing to prevent the inmates of penal institutions from forming their own organization. The general freedom of association applies to them. Likewise, there is nothing to prevent them from electing bodies within the institutions to further their demands (Martinsson 1971:1).

Furthermore, he described the negotiations between the delegates representing all of Sweden's prisoners on one side and the representatives of the Prison Administration and the personnel organizations on the other, as unique in history for placing the different parties on equal footing, for sure an understanding of the situation that certainly differed from that of the prisoners (Martinsson 1971:3-6, my italics).

There is, however, yet another important aspect in the understanding of the strategy of the Prison Administration. Since the 1930s Sweden had worked hard to create a positive international image of the welfare state. One of the key areas that had already begun to attract interest in the 1940s was humanity and progressiveness in criminal policy and prison regimes. During Torsten Eriksson's term as Governor General for the Prison Administration this focus had intensified. This positive image was threatened by the prisoners' unrest and the harsh critique directed at the prisons. At the height of the prison struggle, the Prison Administration published a series of articles and pamphlets in English depicting the on-going reform work in the Swedish prisons and underlining its effective and benevolent character. ${ }^{12}$ Several responses, primarily from the USA, bear witness to this campaign's success. So, at the same time as the Prison Administration was under heavy fire at home from $K R U M$, liberal-minded politicians and most of the big newspapers, they were praised for their humanitarianism and progressiveness abroad, most notably in the USA. (Nilsson 2012).

But the struggle between $K R U M$ and the Prison Administration also applied to the image of the subject. If $K R U M$ 's dominant strategy for changing the power relations in prisons for $K R U M$ built on a liberal view, where the prime effect would be to enhance individual freedom and autonomy, the Prison Administration presented an alternative view. Thus, instead of perceiving the benefit of prison democracy to be in the freedom of the liberal subject, the Prison Administration argued that by granting the inmates rights they can would be in a better posi-

12. The titles on the publications are telling, "Prison Democracy", "Opening up the Prisons", "In for repairs" and "Where prisoners are people" often published in Sweden Now, edited by the Swedish Information Service in New York. Also, interesting in this context is that the name denoting the Swedish Prison Administration in older publications, "Swedish Correctional Administration", was now changed to "Swedish Prison Service". 
tion to contribute to the welfare of the social whole and feel greater loyalty to society. Moreover, by learning democratic rules and being given opportunities to participate in the democratic process, the chances of identifying with society would increase. A stronger association with society tends to reduce the likelihood of prisoners and ex-prisoners' committing crimes, and, therefore, inculcation of social attitudes and training in democratic practice would contribute to reducing the risk of relapsing into crime. Hence, the aim of the Prison Administration was not to produce a liberal, self-steering subject but a social subject. Bo Martinsson once again:

In my reasoning I have taken for granted that participation in democratic organizations and cooperation in democratic forms would have an improving effect on the inmates. It can be hoped that the inmate experiences a new identification - as member or leader of a social movement aiming at the reforming of the prison society - and leaves his old criminal identification behind. This might help him to take a new look at himself at his discharge. If he engages in social and activities this might keep him from committing new crimes (Martinsson 1971:3-4).

Lastly, not all claims put forward by the prisoners belonged to the sphere of political rights. As the prisoners' demands grew, they came to include a list of what they saw as ameliorations and improvements of daily life in prison. In relation to the discussion above, the important point is that these claims were mostly intended to limit the effects of disciplinary power, i.e. the kind of power that the prisoners were confronted with on a regular basis, and have much less to do with abstract liberal rights. Thus, the prisoners' demands for changes in the rules and norms that constituted the "practical" and everyday relations in prison, i.e. those relations that really determine the character of the regime, were directed at the disciplinary power in prisons. And while it is reasonable to believe that most prisoners would support such demands, it is equally reasonable to believe that most prisoners had difficulty identifying with the demands for abstract liberal rights.

\section{Conclusion}

In this article, I have discussed some aspects of KRUM and the prison struggle, most importantly the role of prisoners' rights. The ideological ground for adopting a prisoners' rights strategy for reforming, and perhaps even abolishing, the prisons was a critique of the existing prison regime inspired by a variety of sources: social science research, professional practice, and legal critiques, as well as the writings of journalists and "cultural workers". Thus, a prison-critical dis- 
course was produced that included everything from well-researched prison sociology to grotesque exaggerations in which life in Swedish prison colonies was equated with life in the Auschwitz concentration camp (Svenstedt 1971).

For KRUM and the prisoners, the prisoners' councils and their associated rights were seen as the gateway through which they could introduce a real "prison democracy", something that would radically alter the power relations within the prison system. The recognition of the prisoners' councils - and, most dramatically, the strikes that they initiated - was the battering ram that would demolish the prison walls from the inside. However, the eventual outcome demonstrated that relying on the rights platform could, at best, result in minor cracks. Their failure may also be explained by the fact that $K R U M$, given its liberal roots, fought with, if not with the wrong tools, at least with insufficient ones. KRUM presented a strong critique of the Prison Administration. However, the administration did not react by defending the treatment of individuals on medical or psychological grounds, but - predictably primarily concentrated in maintaining order and control. Medical and psychological grounds had a much weaker position than the critics realized, in practise they were greatly overshadowed by a model built on work-training in large collective units.

Prisoners' rights allow for prisoners to become political citizens or, in other words, political subjects; a position which would both enhance and protect the prisoners' ability to take action. But gaining rights is only one prerequisite for the real transformation of power relations, which can never be altered by an expansion of the sphere of rights alone. Neither are they stable, as the history of rights shows, because they are subject to processes of transformation. What has been won in one context may be lost in another. Thus, in recent years, most of the cracks that could be seen in the prison walls in the 1960s and 1970s have been solidly repaired.

In a sense, the failure of the prison struggle was not only the result of a situation where the prisoners lacked the opportunity to be "positive" contributors to the system, nor of the fact that the Prison Administration were more skilful negotiators; it also illustrated the flaws in the liberal-democratic conception of rights when it comes to social and political struggles of the kind dealt with here. For $K R U M$, prisoners' rights were political only in the sense that they aimed to create a space in which the prisoners could claim these rights. By simply rejecting much of the penal welfarism of the post-war period and replacing it with the rights 
model, KRUM failed to change the prisoners' socially and economically alienated position. ${ }^{13}$

The prison struggle of the late 1960s and early 1970s is long since past, and may at best be remembered with a certain amount of nostalgia by old KRUM members. But even though $K R U M$ was far from reaching their rather high-flying goals, the prison struggle had positive effects. By providing legal expertise and advice, forging relationships with political groups and, most importantly, through their success in securing coverage and almost unanimous backing from the leading media outlets, KRUM played a key role. Furthermore, in the same way as the formation of $K R U M$ and their support of the prisoners was a necessary precondition for this struggle to take shape, the existence of $K R U M$ was also one factor that led to changes in criminal policy during the 1970s. Lastly, if we look at the prisoners themselves, by entering into the prison struggle, they took part in a distinctly political action as prisoners for the first time. Even if it was only for a short period, the prisoners nevertheless manifested themselves as political subjects, and, by a sort of performative exercise succeeded in challenging the power relations inside the prisons in a way that had never been done before.

\section{Referenslista}

Adamsson, M. et al. (red.) (2004). När botten stack upp: Om de utslagnas kamp för frihet och människovärde. Möklinta: Gidlunds.

Arvidsson, H. (2008). Vi som visste allt. Minnesbilder från 1960-talets vänsterrörelse. Stockholm: Atlantis.

Berntson, L. \& Nordin, S. (2017). Efter revolutionen. Vänstern i svensk kulturdebatt sedan 1968. Stockholm: Natur \& Kultur.

Bjereld, U. \& Demker, M. (2005). I vattumannens tid? En bok om 1968 års auktoritetsuppror och dess betydelse idag. Stockholm: Hjalmarsson \& Högberg.

Bjereld, U. (2015). Jag är fri. Lennart Geijer och hans tid. Stockholm: Atlas.

Björkman, J. (2001). Vård för samhällets bästa: Debatten om tvångsvård i svensk lagstiftning 1850-1970. Stockholm: Carlssons.

Buss, H. (1970). "In for Repairs”. Sweden Now. Swedish Information Service.

Easton, S. (2011). Prisoner's Rights: Principles and Practice. Abingdon \& New York: Routledge.

Foucault, M. (1991). Discipline and Punish: The Birth of the Prison. Harmondsworth: Penguin.

13. This was basically left to the grass-roots work carried out in the form of prison visit groups, prisoners' friend committees and work with released prisoners organized by KRUM. This work, however, suffered in most chapters from lack of continuity and insufficient resources. It is worth noting that a considerable amount of this kind of work, in contrast to the "highprofile" work visible in public and media contacts, was carried out by female members. 
Garland, D. (1985). Punishment \& Welfare: A History of Penal Strategies. Aldershot: Gower.

Gahrton, P. "20 år sedan KRUM grundades. Rättsröta och svikna illusioner", i Adamsson et al 2004.

Golder, B. \& Fitzpatrick, P. (2009). Foucault's Law. Abingdon \& New York: Routledge.

Golder, B. (2015). Foucault and the Politics of Rights. Stanford: Stanford University Press.

Inghe, G. \& Inghe, M.-B. (1967). Den ofärdiga välfärden. Tiden/Folksam.

Jonsson, G. (1969). Det sociala arvet. Stockholm: Tiden.

Källström, S. (1984). Värdenihilism och vetenskap. Uppsalafilosofin i forskning och samhällsdebatt. Göteborg: Acta.

Lazarus, L. (2004). Contrasting Prisoners' Rights: A Comparative Examination of Germany and England, Oxford: Oxford University Press.

Lennerhed, L. (1989). Välfärdens rebeller. Sveriges Liberala Studentförbund och kulturradikalismen under 1960-talet. Stockholm. Stockholms universitet. Avdelningen för idéhistoria.

Link, R. (1973). "Where Prisoners are People". Sweden Now. Swedish Information Service.

Lundberg, S. (1993). Sextioåttor. En studie av en politisk generation. Stockholm: B Östlings bokförlag Symposion.

Martinsson, B. (1971). "Prison Democracy in Sweden". Swedish Information Service.

Mathiesen, T. (1965). The Defences of the Weak. A Sociological Study of a Norwegian Correctional Institution. London: Tavistock Publications.

Mathiesen, T. (1972). Det ofullgångna: Bidrag till politisk aktionsteori. Stockholm: Wahlström \& Widstrand.

Mathiesen, T. (1974). The Politics of Abolition: Essays in Political Action Theory. Oslo: Universitetsforlaget.

Mathiesen, T. (2015). The Politics of Abolition Revisited. London \& New York: Routledge.

Mathiesen, T. (2017). Cadenza. A professional autobiography. London. EG Press Limited.

Molander, J. (2002). Straffets grammatik. Åbo: Åbo Akademis förlag.

Nilsson, R. (2012). “The most progressive, effective correctional system in the world': the Swedish prison system in the 1960s and 1970s", in Thomas Ugelvik \& Jane Dullum (red.), Penal Exceptionalism? Nordic Prison Policy and Practice, London and New York: Routledge.

Nilsson, R. (2013). Från cellfängelse till beteendeterapi: Fängelse, kriminalpolitik och vetande 1930-1980. Malmö: Égalité.

Nilsson, R. (2017). “"First We Build the Factory, Then We Add the Institution', i Peter Scharff Smith \& Thomas Ugelvik (red.), Scandinavian Penal History, Culture and Prison Practice. Embraced By the Welfare State? London: MacMillan.

Petersson-Hjelm, A.-C. (2002). Fängelset som välfärdsbygge. Tre studier om behandlingstanken i svensk kriminalvård. Uppsala: Uppsala Universitet.

Pickett, B. (2006). The Use and Abuse of Foucault for Politics. Lanham: Lexington Books.

Salomon, K. (1996). Rebeller $i$ takt med tiden. FNL-rörelsen och 60-talets politiska ritualer. Stockholm: Rabén Prima.

Schön, L. (2010). Sweden's road to modernity: An economic history. Stockholm: SNS.

Smith, D. (1974). “Opening up the Prisons”. Current Sweden. No 53.

Svenstedt, C-H. (1971). Fängelse en (1) månad. Stockholm: Aldus/Bonnier.

Tham, H. "Hur ska vi ha det med KRUM?". Krumbukt nr 1 1972, 2-3. 
Tham, H. "KRUM:s nedgång och fall”, i Adamsson et al 2004.

Ward, D. "Sweden: The Middle Way to Prison Reform?", i Marvin E Wolfgang (red.), Prisons: Present and Possible. Lexington, Mass.: Lexington Books 1979, 125-130.

Östberg, K. (2002). 1968 när allting var i rörelse. Sextiotalsradikaliseringen och de sociala rörelserna. Stockholm: Prisma.

Östberg, K. (2008). "Sweden and the long '1968': break or continuity?”. Scandinavian Journal of History. Vol. 33, No 4, 339-352. 